Ma. Theresa L. Gumban, RN, MD Natividad A. Almazan, MD, MSC

Department of Otorhinolaryngology Head and Neck Surgery

East Avenue Medical Center

Diliman, Quezon City, Philippines

\section{Postoperative Wound Complications in Modified Meatoplasty vs Z- Meatoplasty in Canal Wall Down Mastoidectomy at a Tertiary Hospital: A Randomized Controlled Trial}

\section{ABSTRACT}

Objective: To compare the postoperative complications (narrowing of the enlarged canal and perichondritis) of a meatoplasty without conchal cartilage removal and more raw skin area (modified meatoplasty) versus a meatoplasty with conchal cartilage removal and less raw skin area ( $Z$ meatoplasty) including other sequelae (hyperemia, formation of granulation tissue and discharge from the cavity) which may lead to complications in canal wall down post-auricular mastoidectomy.

\section{Methods:}

Design: Concealed, randomized controlled clinical trial

Setting: Tertiary Public Hospital

Patients: Twenty-one ears of 19 patients with chronic suppurative otitis media (CSOM) undergoing postauricular open mastoidectomy (radical or modified radical mastoidectomy) between February to July 2009 were randomly assigned to undergo modified meatoplasty (Group A: $n=11$ ) and Z meatoplasty (Group B:n=10). Main outcome measures were postoperative rates of meatoplasty complications and mastoidectomy sequelae that may lead to complications on weeks 1,2 and 4.

Results: On the first postoperative week, the $Z$ meatoplasty was associated with a higher incidence of hyperemia at the incision site [A:36.4\%, B: $90 \%(p<0.02)]$. The specific complication of perichondritis or other sequelae (discharge from the cavity, granulation tissue) were no different in both types of meatoplasty. On the second postoperative week, the modified meatoplasty was associated with a higher incidence of narrowing of the canal (73\% vs $20 \%) \mathrm{P}<0.02 ;[R R=3.64$ ( $\mathrm{Cl}: 1.00,13.23)]$ The only factor associated with this complication was the modified meatoplasty procedure itself $[\mathrm{RR}=3.64(\mathrm{Cl}: 1.00,13.23)]$. Perichondritis and the sequelae of mastoidectomy (discharge from the cavity, granulation tissue) were no different in both types of meatoplasty.

Conclusion: Among CSOM patients who underwent postauricular open mastoidectomy, the $Z$ meatoplasty was associated with a greater risk of hyperemia at the incision site than the modified meatoplasty in the first operative week. Compared to the $Z$ meatoplasty, the modified meatoplasty was associated with greater risk of narrowing of the canal on the second postoperative week.

Keywords: meatoplasty, mastoidectomy, complications 
Meatoplasty refers to surgically altering the shape or size of the external opening (meatus) of the external auditory canal. This portion of the ear canal is surrounded by cartilage. Therefore meatoplasty is an operation on the skin and cartilage of the lateral one third of the external auditory canal. It is commonly done after performing mastoidectomy, regardless of approach.'

Before meatoplasty was developed by Stacke (1893) and Schwartze (1893) followed by Panse, Korner, Ballance and Siebermann, the intentional creation of a postaural fistula after mastoidectomy was often done to facilitate management of the unsafe and diseased ear, such as in cases of sinus thrombosis and brain abscess. ${ }^{2}$

Many papers have been published on different types of meatoplasty, showing the advantage of each in creating a wide meatoplasty necessary for a mastoidectomy, entailing removal of conchal cartilage, suturing it backwards, meatal packing or combinations thereof to facilitate a dry, clean, or easy to clean cavity..$^{3-9}$ However, there are very few papers that discuss the postoperative complications of meatoplasty.

Complications of meatoplasty include infection manifested by perichondritis, infected granulation tissue and foul discharge. These may cause narrowing of the external canal and eventual stenosis. In one study, Z meatoplasty had a 4\% incidence of perichondritis (1 in 24 ears) and $12 \%$ incidence of canal stenosis ( 3 in 24 ears). ${ }^{10} \mathrm{~A}$ PubMED search using the terms "meatoplasty, complications" did not reveal any data regarding complications of modified meatoplasty.

This paper aimed to compare the postoperative complications between Z meatoplasty which entails removal of the conchal cartilage and healing by primary intention and modified meatoplasty which preserves the conchal cartilage and heals by secondary intention for patients with chronic suppurative otitis media undergoing canal wall down mastoidectomy via a postauricular approach.

\section{MATERIALS AND METHODS}

Nineteen patients ( 9 males and 12 females aged 15-46 years) diagnosed with chronic suppurative otitis media who underwent postauricular canal down mastoidectomy from February 2009 to July 2009 were included in the study, which was conducted in accord with the Helsinki Declaration of 1975. Fifteen patients were admitted at the Out Patient Department (OPD), three patients at the Emergency Room (ER) and one patient was referred from the Department of Surgery. Two of these patients underwent bilateral mastoidectomy making a total of 21 ears to include in the study. Patients with congenital or acquired external ear abnormalities were excluded.

\section{Randomization}

After approval from the department, separate informed consents for mastoidectomy and inclusion in the study were obtained from the patients or their legal guardians. Patients were randomly assigned to undergo meatoplasty with the modified meatoplasty or the $Z$ meatoplasty. Randomization was performed in blocks of two groups. Twenty one pieces of paper numbered 1 to 21 were placed in a bowl and surgeons were asked to draw one piece of paper each to determine the type of meatoplasty to be performed. The trial was concealed with one author holding the list of randomly assigned numbers to either modified meatoplasty or Z meatoplasty. This was accomplished using an internet-based Research Randomizer program (Social Psychology Network, Connecticut; USA). ${ }^{11}$ The authors then informed each surgeon what type of meatoplasty to use.

\section{Variables}

The surgeons included in this study had the same level of competency in residency training, but none had performed either modified meatoplasty or Z meatoplasty in previous mastoidectomies. Learning curves were not accounted for, as a pre-randomization training was not conducted. Only one author assessed the variables studied.

\section{Procedure}

Modified Meatoplasty ${ }^{12}$

A modification of the Fisch meatoplasty ${ }^{5}$ was employed with a 12 o'clock endaural incision without removal of conchal cartilage and allowing healing by secondary intention.

The incision is made in the fundus of the external auditory canal at 12 o'clock position, extending radially towards the root of the helix, turning 90 degrees to the direction of the concha, approximately 1.5 to $2 \mathrm{~cm}$ without overpassing the helix (Figure 1). The incision includes the full thickness of the external auditory canal and concha, creating a triangular flap with inferior and lateral base (Figure 2). The flap, consisting of skin, soft tissue, cartilage and perichondrium is then rotated in a posterior and inferior direction, then sutured to the digastric muscle using vicryl 3-0 (Ethicon, Johnson \& Johnson: Somerville, New Jersey USA) (Figure 3). ${ }^{1}$ In our study, the authors opted to suture the flap to the soft tissue on the deep surface of the pinna using chromic catgut 3-0 (Ethicon, Johnson \& Johnson: Somerville, New Jersey USA) due to financial constraints.

\section{Z Meatoplasty}

First described by Fagan in $1998^{4}$ and modified by Murray in $2000^{13}$ for use in endaural approach, Tunkel ${ }^{10}$ in 2006 utilized the Z meatoplasty for a postauricular approach mastoidectomy on 24 ears in children with an $87.5 \%$ success rate. Complications noted in $12.5 \%$ (3 ears) were postoperative perichondritis and canal stenosis. 
The incision is made along the posterior and inferior conchal borders and along the posterior ear canal meatus (Figure 4). A flap of conchal skin just above the perichondrium is elevated posterosuperiorly. A posterior canal flap is also made above the perichondrium, this creates an inferiorly based flap. The conchal and posterior external canal cartilage are excised along with underlying soft tissue (Figure 5). The conchal skin flap is then rotated medially and sutured to the deep surface of the pinna using chromic catgut 3-0. The posterior canal flap is rotated laterally and sutured to the edge of the inferior conchal incision using chromic 3-0 (Ethicon, Johnson \& Johnson: Somerville, New Jersey USA) (Figure 6). ${ }^{10}$

Chlorhexadine acetate $0.5 \%$ tulle gras dressing BP (para-tulle ${ }^{\circledast}$. Cotton Craft (pvt.), Ltd. Lahore, Pakistan) or $1 \%$ soframycin (framycetin sulfate) lano-paraffin (anhydrous lanolin 9.95\%) gauze dressing BP (sofra-tulle ${ }^{\oplus}$. Sanofi-Aventis: Mumbai, India) gauze dressing was utilized as a mastoid cavity pack based on availability.

\section{Postoperative Evaluation:}

Patients were followed up on the first and second week post surgery. The following parameters were observed by a single author: 1) presence of hyperemia, discharge from the external canal or granulation tissue and 2) narrowing of the meatus and/or perichondritis.

\section{Statistical Analysis:}

Post hoc computation of the estimation of the study sample size was based on the proportion of the variable, narrowing of the external auditory canal. The sample size was sufficient to make an analysis based on the computed 8 ears per group: Group A (Modified Meatoplasty) and Group B (Z meatoplasty). Randomly assigning 21 patients to each group would allow detection of this difference in rate of narrowing of the canal complication rate with $80 \%$ power and a 2-tailed significance level of 0.5 . No interim analysis was performed. All patients were analyzed in the group to which they were randomly assigned according to the intention-to-treat principle. (Appendix)

Data was encoded and tallied in SPSS version 10 for windows (IBM; Chicago, Illinois, USA). Descriptive statistics were generated for all variables. For nominal data, frequencies and percentages were computed while mean \pm SD were generated for numerical data. Comparison of the different variables was performed using the $T$ test, Fisher Exact test and Chi-square test. Relative Risk (RR) based on confidence intervals was also computed for the variable- narrowing of the external ear canal.

Each sequela or complication was analyzed in the first, second and fourth week postoperatively. All $P$ values were based on two-tailed

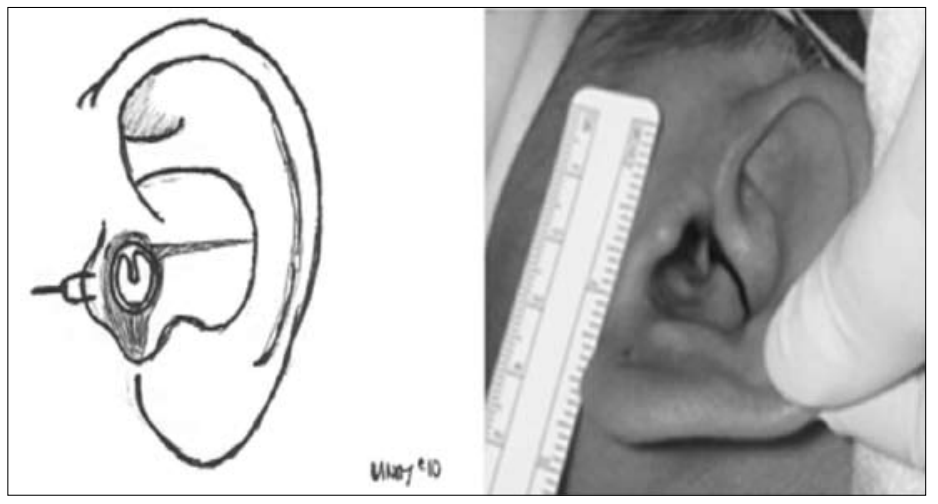

Figure 1. Endaural incision extending to root of helix, turning 90 degrees to concha. Adapted from: Almario JE, Lora JG, Prieto JA, Correa A. Modified meatoplasty surgical technique for canal wall down mastoidectomy. Grupo Médico Otológico. 2005. [cited 2009 Sep]: [about 3 p.] Available from: http:// www.susmedicos.com/articulos_otologia_modified-meatoplasty.htm

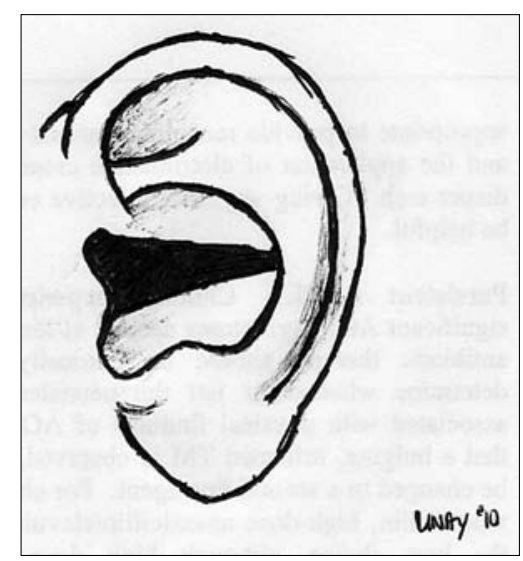

Figure 2. Triangular flap with inferior and lateral base. Adapted from: Almario JE, Lora JG, Prieto JA Correa A. Modified meatoplasty surgical technique for canal wall down mastoidectomy. Grupo Médico Otológico. 2005. [cited 2009 Sep]: [about 3 p.] Available from: http://www.susmedicos.com/articulos otologia_modified-meatoplasty.htm

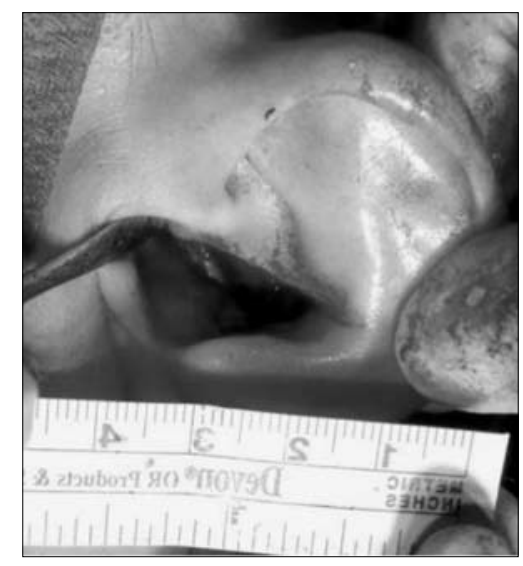

Figure 3. Triangular flap, consisting of skin, soft tissue, cartilage and perichondrium rotated in a posterior and inferior direction, sutured to the digastric muscle. 
ORIGINAL ARTICLES

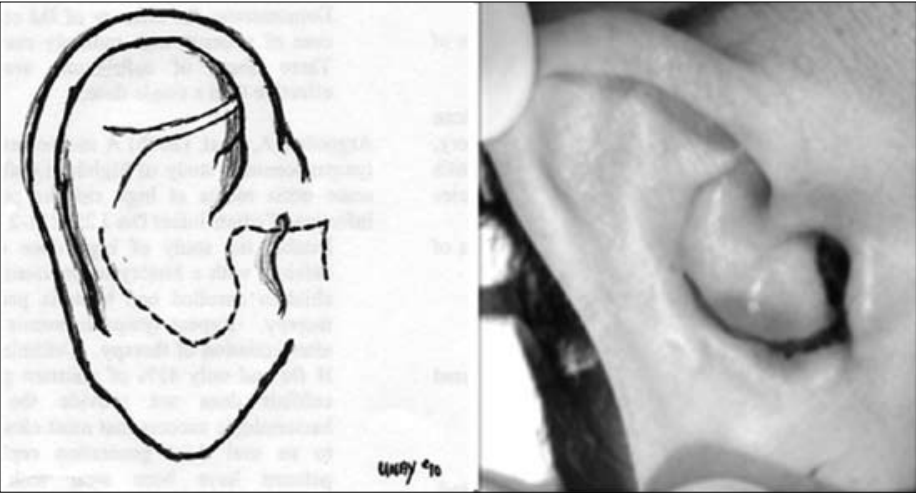

Figure 4. Incision along posterior and inferior conchal borders and posterior canal meatus. Adapted from: Tunkel DE. The Z-meatoplasty for modified radical mastoidectomy in children. Arch Otolaryngo Head Neck Surg. 2006 Dec; 132(1):1319-1322

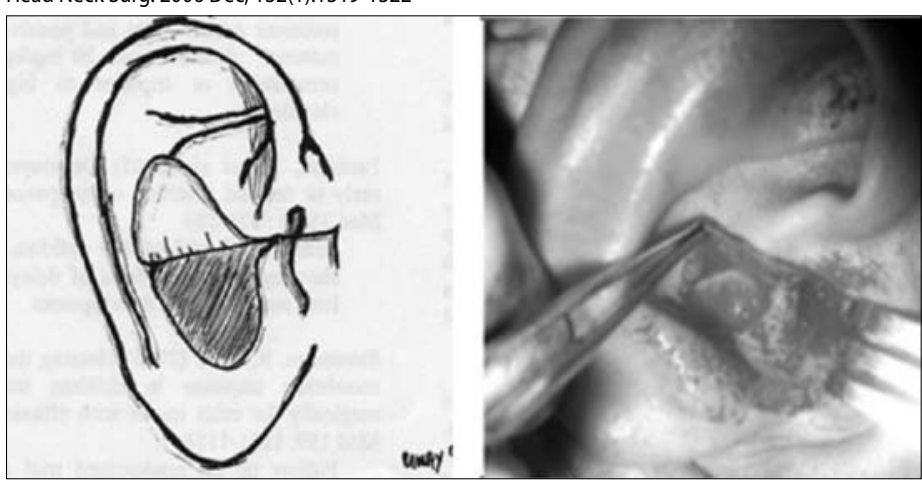

Figure 5. A Conchal skin flap elevated superiorly and inferiorly-based posterior canal flap. Adapted from: Tunkel DE. The Z-meatoplasty for modified radical mastoidectomy in children. Arch Otolaryngol Head Neck Surg. 2006 Dec; 132(1):1319-1322

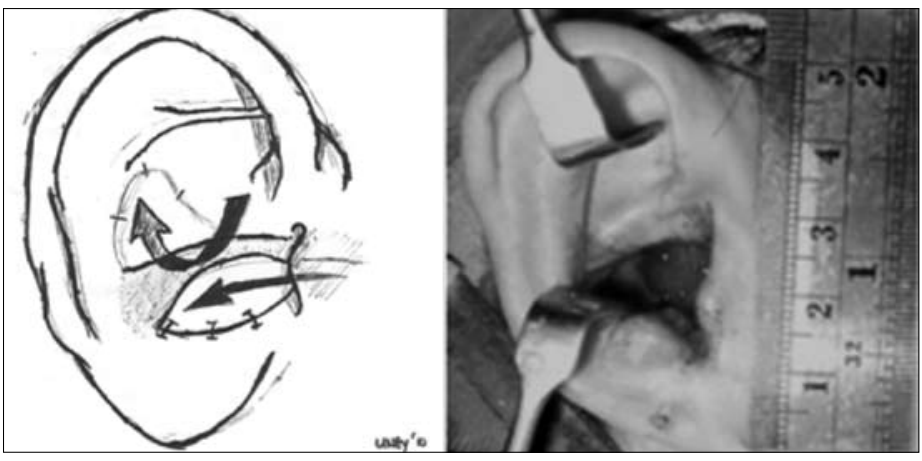

Figure 6. Conchal skin flap rotated medially and posterior canal flap rotated laterally. Adapted from: Tunkel DE. The Z-meatoplasty for modified radical mastoidectomy in children. Arch Otolaryngol Head Neck Surg. 2006 Dec; 132(1):1319-1322

test of significance. The proportions of ears free of complications were compared between Group A (Modified Meatoplasty) and Group B (Z meatoplasty). Variables were considered significant at $\mathrm{P}<0.05$.

\section{RESULTS}

A total of 21 ears were operated on, 11 had modified meatoplasty and 10 underwent Z- meatoplasty. Baseline characteristics were similar in the two groups (Group A: Modified Meatoplasty and Group B: Z meatoplasty (Table 1). These include sex, age and type of mastoidectomy. In Group A, five (45.5\%), were male and six (54.5\%) were female and in Group B, four ( $40 \%)$ were male and six $(60 \%)$ were female $(p=0.84)$. The mean ages for Group A and B were 30 and 31 years old, respectively $(p=1.0)$. There were two types of open mastoidectomy for both groups, the Radical Mastoidectomy and Modified Radical Mastoidectomy. Radical mastoidectomy was performed on eight ears (72.7\%) in Group A and four ears (40\%) in Group B, while modified radical mastoidectomy was performed on three ears (27.3\%) in Group A and six ears (60\%) in Group B ( $\mathrm{P}=0.19)$.

For co-morbidities of the disease (Table 2), cholesteatoma was present in six (54.5\%) and five (50\%) in Groups A and B, respectively; subperiosteal abscess was present in one (9.1\% and $10 \%)$ in Groups $A$ and $B$, respectively; temporal lobe abscess was present in two (18.2\%) and one (10\%) in Group A and B, respectively; and meningitis and facial paralysis were each present in one (9.1\%) in Group A with neither comorbidity present in Group B.

With regard mastoidectomy sequelae, mastoid cavity discharge (Table 3) was not significantly different in Groups A and B at all intervals of observation (first, second and fourth week). Hyperemia (Table 4) was significantly higher in Group B (Z meatoplasty) during the first week than in Group A (modified meatoplasty) [A: 36.4\%, B: $90 \%(p<0.02)$ ]. There was no difference in formation of granulation tissue in Groups $A$ and $B$ on the first, second and fourth week of observation (Table 5).

With regard actual complications of meatoplasty, perichondritis (Table6) was not statistically different in Groups A and B at all observation intervals (first, second and fourth week) but external canal narrowing (Table 7) was significantly higher in Group A, modified meatoplasty with eight ears (72.7\%) compared to Group B, Z meatoplasty with 2 ears $(20 \%)$ at the second week of observation $(p<0.02)[R R=3.64$ (Cl:1.00,13.23)].

\section{DISCUSSION}

Although fairly standard, meatoplasty is possibly the most neglected and often the worst performed part of the mastoid operation. ${ }^{3}$ An adequate meatoplasty more often than not makes up for a less than adequate bony exteriorization. ${ }^{3}$

The meatoplasty is necessary for the correct exteriorization and selfcleansing property of an open cavity and is made as large as required by the shape of the bony cavity. In a chart review by Phelan et al. ${ }^{15} 9$ out of 37 cases (24\%) had an inadequate meatus requiring revision mastoidectomy. Similar studies by Bercin ${ }^{16}$ and Faramarzi ${ }^{17}$ showed 14 out of 21 patients $(66.7 \%)$ and 16 out of $53(30 \%)$ respectively, while a study by Yang and Chiong ${ }^{18}$ found 10 out of 24 patients (42\%) who 
had radical mastoidectomy failed due to an inadequate meatus. In our study, third year residents completing their requirements for mastoidectomy procedures including the author who did the assessment were the main surgeons. Although the surgeons each had nearly completed half the number of required mastoidectomies in their residency training program at the time of this study, none of them had previously performed either a modified or Z meatoplasty nor had pre-randomization training been conducted. These should also be considered in assessing results of our study.

While ear discharge that eventually dries up is an expected sequel of mastoidectomy, persistent and foul discharge after mastoidectomy may result from an inadequately drilled mastoid bowl, a high facial ridge and residual infection. Although this was not assessed in our study, a common factor was the surgical procedure of radical mastoidectomy (which may also have been reflective of worse ears to begin with compared to those that needed modified radical mastoidectomy only). Although the difference between the two groups was not significant, there was a trend of decreasing $p$ value from the first week to the fourth week ( $p=$ first week, 1.00; second week, 0.66 and fourth week, 0.15 ). Perhaps with a longer period of observation, the discharge would no longer be present as the cavity re-epithelialized. None of the discharge noted originated from the meatoplasty incision site.

An inflammatory response starts with increased blood flow due to vasodilation, causing hyperemia; and increased vascular permeability leads to edema and a cascade of immune responses. ${ }^{19}$ Reactive hyperemia is the transient increase in blood flow following a brief period of ischemia. Influx of vasoactive substances in response to prolonged stress further contributes to this. The redness at the edges of the meatoplasty incision may represent the initial phase of revascularization, possibly exacerbated by more skin manipulation as seen on Group B. In the first week, the incidence of hyperemia was found to be higher in Group B ( $Z$ meatoplasty) $p<0.02$. Although there was a trend of decreasing hyperemia in the second week (90\% to $40 \%$ ), this was not statistically significant.

Perichondritis, an infection of the skin and tissue surrounding the cartilage of the outer ear presents with erythema, edema and exquisite tenderness. ${ }^{20}$ The most common causative organism is $P$. Aeruginosa. ${ }^{21}$ In our study, perichondritis was found only in Group A at the first week (18.2\%) and second week (36.4\%). Interestingly, all of these patients had granulation tissue formation which may indicate a persisting inflammatory response to infection. Incising but not removing cartilage and suturing it posteroinferiorly in Group A may have increased the chance of exposure to ear discharge from the mastoid cavity contributing to perichondritis.
Table 1. Comparison of the Demographic Characteristics Between the Modified Meatoplasty and the $Z$ meatoplasty

\begin{tabular}{l|c|c|c}
\multicolumn{1}{c|}{ Variables } & $\begin{array}{c}\text { Group A } \\
\text { Modified Meatoplasty } \\
(\mathrm{n}=11)\end{array}$ & $\begin{array}{c}\text { Group B: } \\
\mathbf{Z} \text { meatoplasty } \\
(\mathrm{n}=10)\end{array}$ & P value \\
\hline \begin{tabular}{l|c|} 
Age (in years) \\
Mean \pm SD
\end{tabular} & $30.09 \pm 9.85$ & $31.00 \pm 10.61$ & 0.84 (NS) \\
\hline Sex & $5(45.5 \%)$ & $4(40.0 \%)$ & 1.00 (NS) \\
Male & $6(54.5 \%)$ & $6(60.0 \%)$ & \\
Female & & & \\
\hline Type of Mastoid Surgery & $3(27.3 \%)$ & $6(60.0 \%)$ & 0.19 (NS) \\
Modified Radical Mastoidectomy & $8(72.7 \%)$ & $4(40.0 \%)$ & \\
Radical Mastoidectomy &
\end{tabular}

Table 2. Distribution of Subjects According to Comorbidity Between the Modified Meatoplasty and the $Z$ meatoplasty

\begin{tabular}{l|c|c|c}
\multicolumn{1}{c|}{ Comorbidity } & $\begin{array}{c}\text { Group A } \\
\text { Modified Meatoplasty } \\
(\mathrm{n}=11)\end{array}$ & $\begin{array}{c}\text { Group B: } \\
\mathbf{Z} \text { meatoplasty } \\
(\mathrm{n}=10)\end{array}$ & P value \\
\hline Cholesteatoma & $6(54.5 \%)$ & $5(50.0 \%)$ & \\
$(+)$ & $5(45.5 \%)$ & $5(50.0 \%)$ & 1.00 (NS) \\
$(-)$ & $1(9.1 \%)$ & 0 & \\
\hline Meningitis & $10(90.9 \%)$ & $10(100 \%)$ & 1.00 (NS) \\
$(+)$ & $1(9.1 \%)$ & $1(10.0 \%)$ & \\
$(-)$ & $10(90.9 \%)$ & $9(90.0 \%)$ & 1.00 (NS) \\
\hline Subperiosteal Abscess & $1(9.1 \%)$ & 0 & \\
$(+)$ & $10(90.9 \%)$ & $10(100 \%)$ & 1.00 (NS) \\
$(-)$ & & $1(10.0 \%)$ & \\
\hline Facial Nerve Paralysis & $2(18.2 \%)$ & $9(90.0 \%)$ & 1.00 (NS) \\
\hline$(+)$ & $9(81.8 \%)$ & \\
$(-)$ & Temporal Lobe Abscess & &
\end{tabular}

Table 3. Distribution of Subjects According to Discharge at Different Intervals Between the Modified Meatoplasty and the Z meatoplasty

\begin{tabular}{|c|c|c|c|}
\hline Interval & $\begin{array}{l}\text { Modified } \\
(n=11)\end{array}$ & $\begin{array}{c}\mathbf{Z} \\
(n=10)\end{array}$ & Pvalue \\
\hline \multicolumn{4}{|l|}{1 week } \\
\hline$(+)$ & $8(72.7 \%)$ & $8(80.0 \%)$ & 1.00 (NS) \\
\hline$(-)$ & $3(27.3 \%)$ & $2(20.0 \%)$ & \\
\hline \multicolumn{4}{|l|}{2 weeks } \\
\hline$(+)$ & $8(72.7 \%)$ & $6(60.0 \%)$ & 0.66 (NS) \\
\hline$(-)$ & $3(27.3 \%)$ & $4(40.0 \%)$ & \\
\hline \multicolumn{4}{|l|}{4 weeks* } \\
\hline$(+)$ & 6 & 2 & 0.15 (NS) \\
\hline$(-)$ & 3 & 6 & \\
\hline
\end{tabular}

* $p$ value at 4 weeks with intention to treat making the lost to ff-up neg $=0.18$ $p$ value at 4 weeks with intention to treat making the lost to ff-up pos $=0.19$ $\mathrm{p}$ value at 4 weeks with intention to treat making the lost to ff-up pos $/$ neg $=0.19$ 
Table 4. Distribution of Subjects According to Hyperemia at Different Intervals Between the Modified Meatoplasty and the $Z$ meatoplasty

\begin{tabular}{|c|c|c|c|}
\hline Interval & $\begin{array}{c}\text { Group A: } \\
\text { Modified Meatoplasty } \\
(\mathrm{n}=11)\end{array}$ & $\begin{array}{c}\text { Group B: } \\
\text { Z meatoplasty } \\
(n=10)\end{array}$ & $P$ value \\
\hline $\begin{array}{l}\frac{1 \text { week }}{(+)} \\
(-)\end{array}$ & $\begin{array}{l}4(36.4 \%) \\
7(63.6 \%)\end{array}$ & $\begin{array}{l}9(90.0 \%) \\
1(10.0 \%)\end{array}$ & $0.02(S)$ \\
\hline $\begin{array}{l}2 \text { weeks } \\
(+) \\
(-)\end{array}$ & $\begin{array}{l}5(45.5 \%) \\
6(54.5 \%)\end{array}$ & $\begin{array}{l}4(40.0 \%) \\
6(60.0 \%)\end{array}$ & 1.00 (NS) \\
\hline $\begin{array}{l}4 \text { weekst } \\
(+) \\
(-)\end{array}$ & $\begin{array}{l}2 \\
7\end{array}$ & $\begin{array}{l}1 \\
7\end{array}$ & 1.00 (NS) \\
\hline
\end{tabular}

t $p$ value at 4 weeks with intention to treat making the lost to ff-up neg $=1.00$ $p$ value at 4 weeks with intention to treat making the lost to ff-up pos $=1.00$ $\mathrm{p}$ value at 4 weeks with intention to treat making the lost to ff-up pos $/$ neg $=1.00$

Table 5. Distribution of Subjects According to Granulation at Different Intervals Between the Modified Meatoplasty and the $Z$ meatoplasty

\begin{tabular}{l|c|c|c}
\hline Interval & $\begin{array}{c}\text { Group A: } \\
\text { Modified Meatoplasty } \\
(\mathrm{n}=11)\end{array}$ & $\begin{array}{c}\text { Group B: } \\
\mathbf{Z} \text { meatoplasty } \\
(\mathrm{n}=10)\end{array}$ & P value \\
\hline$(+)$ & $7(63.6 \%)$ & $6(60.0 \%)$ & 1.00 (NS) \\
$(-)$ & $4(36.4 \%)$ & $4(40.0 \%)$ & \\
\hline$\underline{2 \text { weeks }}$ & $10(90.9 \%)$ & $7(70.0 \%)$ & 0.31 (NS) \\
$(+)$ & $1(9.1 \%)$ & $3(30.0 \%)$ & \\
\hline$(-)$ & 4 & 2 & 0.61 (NS) \\
\hline 4weeks§ & 5 & 6 & \\
\hline$(+)$ & & &
\end{tabular}

$\S p$ value at 4 weeks with intention to treat making the lost to ff-up neg $=0.64$ $p$ value at 4 weeks with intention to treat making the lost to ff-up pos $=0.67$ $\mathrm{p}$ value at 4 weeks with intention to treat making the lost to ff-up pos $/ \mathrm{neg}=0.65$

Table 6. Distribution of Subjects According to Perichondritis at Different Intervals Between the Modified Meatoplasty and the $Z$ meatoplasty

\begin{tabular}{|c|c|c|c|}
\hline Interval & $\begin{array}{c}\text { Group A: } \\
\text { Modified Meatoplasty } \\
(\mathrm{n}=11)\end{array}$ & $\begin{array}{c}\text { Group B: } \\
\text { Z meatoplasty } \\
(\mathrm{n}=10)\end{array}$ & P value \\
\hline \multicolumn{4}{|c|}{ 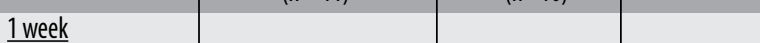 } \\
\hline$(+)$ & $2(18.2 \%)$ & 0 & 0.48 (NS) \\
\hline$(-)$ & $9(81.8 \%)$ & $10(100 \%)$ & \\
\hline \multicolumn{4}{|l|}{2 weeks } \\
\hline$(+)$ & $4(36.4 \%)$ & 0 & 0.09 (NS) \\
\hline$(-)$ & $7(63.6 \%)$ & $10(100 \%)$ & \\
\hline \multicolumn{4}{|l|}{4 weeks $\ddagger$} \\
\hline$\overline{(+)}$ & 2 & 0 & 1.00 (NS) \\
\hline$(-)$ & 9 & 10 & \\
\hline
\end{tabular}

$\neq p$ value at 4 weeks with intention to treat making the lost to ff-up neg $=0.48$ $p$ value at 4 weeks with intention to treat making the lost to ff-up pos $=0.64$ $\mathrm{p}$ value at 4 weeks with intention to treat making the lost to ff-up pos $/ \mathrm{neg}=0.58$
The conchal cartilage is an extremely elastic structure with uniform thickness in its upper two-thirds that gradually increases in thickness towards its inferior aspect. ${ }^{22}$ It is malleable but is not permanently distorted from its original shape with increasing stress. However, the strain of conchal cartilage is dependent on the abundance of elastic fibers and increases the flexibility of the cartilage in response to stress. Simply, conchal cartilage is dependent on the elastic memory or cartilage recoil. Narrowing of the meatoplasty was assessed by the capability to visualize the mastoid cavity. If the pinna had to be manipulated to view the cavity, the meatoplasty was considered inadequate. In Group A (modified meatoplasty), resection of the skin at the superior edge and pulling of conchal cartilage inferiorly and posteriorly created a wide (albeit, inferoposteriorly-displaced) cavity. The subcutaneous tissue and cartilage adds bulk to the pulled-back concha and this may be the major factor for the $72.7 \%$ narrowing of the canal seen during the second week post operation. Posterior rotation of the auricle may have been prevented by placing several sutures deep into the soft tissue more superiorly with retraction of the auricle anteriorly. ${ }^{18}$ Suturing to the undersurface of the pinna instead of utilizing the digastric muscle obviated the need for additional sutures. Insufficient extension of the incision towards the helical root and further modification of the surgical technique by substituting a weaker, more affordable chromic suture may also have contributed to the narrowing of the canal. In Group B (Z-meatoplasty), the conchal cartilage, perichondrium and soft tissues were removed and the skin sutured via z-plasty using chromic catgut with little skin tension. The relative risk of narrowing of the external auditory canal was 3.64 higher in Group A than in Group B on the second week of observation. This was the only variable with significant differences in the two groups on the second week $(p<0.02)$.

Restoration of vascular integrity is part of the proliferative phase of healing and is termed angiogenesis. Angiogenesis occurs as new capillary buds arising from intact vessels adjacent to the wound extend into the wound bed forming a capillary bed. To the naked eye, the capillary loops look like small granules, explaining the term- granulation tissue. ${ }^{23}$ Granulation tissue first appears as pale, pink buds and as it fills with new blood vessels it becomes bright "beefy" red. As it covers the wound, this granulation tissue is very fragile and unable to withstand trauma which may cause bleeding and re-initiate the inflammatory process with laying down of excessive collagen. This results in poor elasticity and a less desirable $s c a r .{ }^{23} \mathrm{~A}$ mature phase eventually ensues whereby the granulation tissue forms a well developed fibrous plug lined by squamous epithelium, ${ }^{24}$ causing soft tissue stenosis.

On the first and second week, both Group A (63.6\%, 90.9\%) and 
Group B $(60 \%, 70 \%)$ had a high incidence of the development of granulation tissue. Although Group A had larger raw areas for healing by secondary intention, Group B also developed granulation tissue. While this may reflect the normal healing process, it may also result from basically unclean mastoidectomy cavities exposing both groups to infection. Whether the use of chlorhexidine tulle gras or soframycin gauze dressing had an effect on granulation tissue formation was not documented in this study either.

The goal of surgery is to achieve primary intention healing with minimal edema, no serious discharge or infection without separation of wound edges and with minimal scar formation. In meatoplasty, surgical incisions are allowed to heal by delayed primary intention and the wound is initially left open. Wound edges in this case are brought together at about 4-6 days before granulation tissue is visible. ${ }^{25}$ This method is often used after traumatic injury or "dirty" surgery. Because of the presence of infection and excessive trauma or skin loss in mastoidectomy and meatoplasty, the wound edges come together naturally by means of granulation and contraction ${ }^{26}$ as seen in our cases.

The natural healing process dictates that granulation tissues begin to be visible by the first week and as the aural pack is to be removed after one week, the template for the canal outline is also removed. This may explain the outgrowth of granulation tissue in the second week in both groups. Group A (modified meatoplasty) had larger raw areas that allowed healing by secondary intention, promoting the outgrowth of more granulation tissue. Additional trauma and contaminants brought about by egress of discharge from the mastoid may explain the increased number of ears with higher relative risks of developing narrowing of the canal after modified meatoplasty in Group A, 3.64x higher than after Z meatoplasty in Group B.

In the first week, the post operative complication of perichondritis and mastoidectomy sequelae of granulation tissue formation and mastoid cavity discharge showed no significant difference between the two groups.

Among CSOM patients who underwent postauricular open mastoidectomy, the $Z$ meatoplasty was associated with a greater risk of hyperemia at the incision site than the modified meatoplasty in the first operative week [A: $36.4 \%, B: 90 \%$ ( $p<0.02)$ ]. Compared to the Z meatoplasty, the modified meatoplasty was associated with a greater risk of narrowing of the canal on the second postoperative week $(73 \%$ vs $20 \%) \mathrm{P}<0.02$; [RR $=3.64(\mathrm{Cl}: 1.00,13.23)]$.

Data collection was stopped due to the increasing number of patients who underwent modified meatoplasty having narrowing of the canal based on the intention-to-treat principle and revision surgery was offered to the four patients who had persistence of the narrowing after three months.

Table 7. Distribution of Subjects According to Narrowing at Different Intervals Between the Modified Meatoplasty and the $Z$ meatoplasty

\begin{tabular}{|c|c|c|c|}
\hline Interval & $\begin{array}{c}\text { Group A: } \\
\text { Modified Meatoplasty } \\
(\mathrm{n}=11)\end{array}$ & $\begin{array}{c}\text { Group B: } \\
\text { Z meatoplasty } \\
(n=10)\end{array}$ & P value \\
\hline \multicolumn{4}{|c|}{ 1 } \\
\hline$(+)$ & $6(54.5 \%)$ & $2(20.0 \%)$ & 0.18 (NS) \\
\hline$(-)$ & $5(45.5 \%)$ & $8(80.0 \%)$ & \\
\hline \multicolumn{4}{|l|}{ 2 weeks } \\
\hline$(+)$ & $8(72.7 \%)$ & $2(20.0 \%)$ & $0.02(S)$ \\
\hline$(-)$ & $3(27.3 \%)$ & $8(80.0 \%)$ & \\
\hline \multicolumn{4}{|l|}{4 weeks } \\
\hline$(+)$ & 6 & 2 & 0.15 (NS) \\
\hline$(-)$ & 3 & 6 & \\
\hline
\end{tabular}

At 2 weeks

RR (Z meatoplasty) $0.28(0.08-1.00)$

RR (Modified Meatoplasty) $3.64(1.00-13.23)$

I $p$ value at 4 weeks with intention to treat making the lost to ff-up neg $=0.18$ $p$ value at 4 weeks with intention to treat making the lost to ff-up pos $=0.19$ $p$ value at 4 weeks with intention to treat making the lost to ff-up pos $/$ neg $=0.19$ $\mathrm{p}$ value at 4 weeks with intention to treat making the lost to ff-up worst/best $=0.02(S)$ $p$ value at 4 weeks with intention to treat making the lost to ff-up best $/$ worst $=0.66$ 


\section{APPENDIX}

\section{Post Hoc Computation of the sample size based on proportion of narrowing alone}

$n=\frac{[z \alpha \sqrt{2 p q}+z \beta \sqrt{P 1 Q 1+P 2 Q 2}]^{2}}{(P 1-P 2)^{2}} \quad \begin{array}{ll}\text { where }: & \\ & p=\frac{\left(P_{1}+P_{2}\right)}{2} \quad q=1-p\end{array}$

Where:

$\mathrm{n}=$ is the number of subjects needed

$\mathrm{P} 1=72.7 \%=0.727$ (estimated proportion of complication in the modified meatoplasty)

$\mathrm{Q} 1=1-\mathrm{P} 1=1-0.727=0.273$

$\mathrm{P} 2=20 \%=0.20$ (estimated proportion of complication in the $\mathrm{z}$ meatoplasty)

$\mathrm{Q} 2=1-\mathrm{P} 2=1-0.20=0.80$

$\mathrm{p}=(\mathrm{P} 1+\mathrm{P} 2) / 2=(0.727+0.20) / 2=0.4635$

$\mathrm{q}=1-\mathrm{p}=1-0.4635=0.5365$

$\mathrm{Za}=95 \%$ confidence level $=1.96$

$Z \beta=80 \%$ power of the study $=1.28$

$\mathrm{n}=8 /$ group

\section{ACKNOWLEDGMENT}

Special thanks to the first author's co-residents who performed the surgeries: Sherlyn $C$ $\mathrm{Ng}$ Tsai, MD, Cristina S. Nieves, MD and Carolynne F. Unay, MD, who also made the operative procedure illustrations.

\section{REFERENCES}

1. Myers E, Carreria R, Eibling D, Ferris R, Gillman G, Golla S. Operative otolaryngology. $2^{\text {nd }}$ ed.Vol 2. Philadelphia:W B Saunders; 1997. p.1280.

2. Sellars SL. The origins of mastoid surgery. S Afr Med J. 1974 Feb 9; 48(6): 234-242.

3. Raut VV, Rutka JA. The Toronto meatoplasty: enhancing one's results in canal wall down procedures. Laryngoscope. $2002 \mathrm{Nov}$; 112(11): 2093-5

4. Fagan P, Ajal M. Z-meatoplasty of the external auditory canal. Laryngoscope. 1998 Sep; 108:1421-1422

5. Fisch U. Tympanoplasty, mastoidectomy and stapedectomy. New York, NY: Thieme; 2008. p 39

6. Portmann M. "How I do it" —otology and neurotology. A specific issue and its solution. Meatoplasty and conchoplasty in cases of open technique. Laryngoscope. $1983 \mathrm{Apr}$; 93(4):520-522

7. Suskind $\mathrm{DL}$, Bigelow $C D$, Knox GW. Y-modification of the Fisch meatoplasty. Otolaryngol Head Neck Surg. 1999 Jul; 121 (1):126-7.

8. Potsic WP, Cotton RT, Handler SD. Surgical pediatric otolaryngology. New York. Thieme Medical Publishers; 1997. p 54

9. Sanna M, Sunose H, Mancini F. Middle ear and mastoid microsurgery. New York Thieme Medical Publishers: 2003. p 279

10.Tunkel DE. The Z-meatoplasty for modified radical mastoidectomy in children. Arch Otolaryngol Head Neck Surg. 2006 Dec; 132(1):1319-1322.

11. Research Randomizer. Connecticut: Social Psychology Network; c1997-2010 [updated 2007; cited Aug 26,2009]. Available from: http://www.randomizer.org

12. Almario JE, Lora JG, Prieto JA, Correa A. Modified meatoplasty surgical technique for canal wall down mastoidectomy. Grupo Médico Otológico. 2005. [cited 2009 Sep]:Available from: http://www.susmedicos.com/articulos_otologia_modifiedmeatoplasty.htm

13.Murray DP, Jassar P, Lee MSW, Veitch DY. Z-meatoplasty technique in endaural mastoidectomy. J Laryngol Otol. 2000; 114:526-527

14.Cummings CW, Flint PW, Harker LA, Haughey BH, Richardson MA, Robbins KT, Schuller $\mathrm{DE}$, Thomas, JR, editors. Cummings otolaryngology head and neck surgery, $4^{\text {th }} \mathrm{ed}$. Vol 4. Philadelphia (PA): Mosby, c2005. p3082.

15.Phelan $\mathrm{E}$, Harney $\mathrm{M}$, Burns $\mathrm{H}$. Intraoperative findings in revision canal wall down mastoidectomy. Ir Med J. 2008 Jan; 101(1):14.

16.Bercin S, Kutluhan A, Bozdemir K, Yalciner G, Sari N, Karamese O. Results of revision mastoidectomy. Acta Otolaryngol. 2009 Feb; 129(2): 138-141.

17.Faramarzi A, Motasaddi-Zarandy M, Khorsandi MT. Intraoperative findings in revision chronic otitis media surgery. Arch Iran Med. 2008 Mar; 11 (2): 196-199.

18. Yang N, Chiong C. Results of radical mastoidectomy in the Philippine General Hospital. [monograph on the Internet]. Advanced Science and Technology Institute (ASTI); c2009 [cited 2009 Sep]. Available from: http://202.90.159.173/gsdl/collect/actamedi/ index/assoc/HASHdcce.dir/doc.pdf

19.Sell S, Max E. Immunology, immunopathology and immunity. $6^{\text {th }}$ edition, illustrated. New York. ASM press; 2001. p 564

20.Medline plus online encyclopedia. Perichondritis. 2008 Sep 8. [cited sep 2009] Available from: http://www.nlm.nih.gov/medlineplus/ency/article/001253.htm.

21.Glasscock M, Gulya A. Glasscock-Shambaugh surgery of the ear. Chicago. PMPH USA; 2003. p 346-347.

22.Man-Kai Tang $\mathrm{H}$. The conchal cartilage effect of its management on the size of the meatoplasty and the outcome of the open mastoidectiomy. Thesis. Published by University of Hong Kong. 2001 [cited Sep 2009]. Available from: http://hub.hku.hk/ handle/123456789/26623

23. Sussman C, Bates-Jensen B. Wound care: a collaborative practice manual for health professionals. ${ }^{\text {rd }}$ edition. Philadelphia - Baltimore. Wolters Kluwer - Lippincott Williams \& Wilkins. 2007; p.21.

24.Gottrup F. Wound closure techniques. J Wound Care. 1999; 8(8): 397-400.

25.Thomas S. Wound management and dressings. London, UK: Pharmaceutical Press;1990: p. 69-73

26. Haberman R. Middle ear and mastoid surgery. New York. Thieme Medical Publishers 2004. p. 189 